\title{
PUBLICATIONS AND SCHOOLS 1
}

\author{
BY R. M. WATT
}

\author{
Dominion Forest Service, Ottawa, Ontario.
}

The executive of the Canadian Society of Forest Engineers is to be complimented on its alertness to public opinion by providing this opportunity for discussion of public education in forestry.

There is a wave of realization breaking over the world today that natural resources have been misused and wasted, and there is growing desire on the part of the public to prevent waste and conserve these resources.

It is significant that the 1949 Nobel Peace Prize was awarded to Lord John Boyd Orr, former head of the United Nations Food and Agriculture Organization, for his proposals for a world food plan. The press and current magazines are carrying a noticeable increase in articles dealing with conservation. Such books as the "Road to Survival", "Our Plundered Planet", and "This Age of Wood" have been widely read and have caused much discussion.

In Ottawa last year the Post-War Problem Study Group of the Women's University Club devoted a season's study to the "Road to Survival". This year the Science Group of the Women's University Club is carrying on an intensive study of conservation, and the following statements are from their promotional appeal to the general membership:-

"1. Soil, Water, Forests and Wild Life

Far removed as they may seem to be from our particular lives, they are, nevertheless, at the foundation of all our prosperity and happiness. They must be conserved.

Come and discuss it with the Science Group.

II. Children are taught Conservation in the Schools

However, time is short and the whole responsibility for conserving our heritage cannot be passed on to the children. Adult education is likewise important.

Come and learn with the Science Group."

The above is but an indication of what is going on in many local organizations across Canada.

Our field is forest conservation, and now is the time to direct interested public attention towards the forest as a basic resource. An informed public is not attained overnight and public thought is fluid. To be most effectively channeled, public education must start at its most impressionable point, namely the youth of the country.

The schools present an excellent opportunity, for here there can be instillation of dynamic ideas that have the power to change outworn concepts of unlimited resources and wasteful practices.

Publications in schools are but one of the vehicles for educating, and this vehicle it is my privilege to discuss.

Publications for use in schools must be suited to the various age groups 1. Paper presented at the 41st annual meeting of the Canadian Society of Forest Engineers,
Toronto, October 24-26, 1949. 
from the primary grades through the university, and they must be prepared in accordance with accepted teaching methods.

It is the task of trained minds in the forestry profession to provide inspirational, authentic and practical information that will open the eyes and minds of our young people to the vastness and importance of forest conservation as applied to the citizen as an individual and to the nation as a whole.

This is a large order but it is the problem of those who provide educational material for the schools. However, it is not a new problem since much good material has been supplied over the years by the various forest services across Canada. The Dominion Forest Service pioneered in this field of publicity as far back as 1920 with carefully prepared publications for use in elementary schools. "Talking Trees", was published at that time and could be used today effectively in elementary schools.

In preparing for the "Save the Forest Week" campaigns which were carried on in the interest of forest fire prevention from 1925 to 1928, we found there was little forest literature available for schools. So great was this lack of suitable information that the Dominion Forest Service decided to provide booklets, leaflets, playlets and even to prepare school programmes so as to ensure the participation of all schools throughout Canada in these concerted drives for public support and understanding.

In 1928 the Dominion Forest Service published a booklet with an attractive Indian design on its cover, entitled, "Forestry Lessons". This booklet combined scientific fact, poetry and the lesson quiz, all of which were within the child's experience, or frame of reference. It was distributed to elementary and high schools in the Prairie Provinces, to the schools of British Columbia, to those in Ontario and Quebec, and finally to those in the Maritime Provinces and Newfoundland. At the request of the Conservator of Forests, Trinidad, it became a basis for text in the Trinidad schools. "Forestry Lessons" was published in French and English, and in 1948 it went to the University of Toronto (to be used as a reference for Junior, French, Faculty of Forestry). It has gone through six impressions and the last edition appeared in 1947. This national distribution was achieved through the splendid co-operation of the Departments of Education of the various provinces.

The reason for this widespread use of "Forestry Lessons" is that, in addition to its attractive presentation, it is inspirational and is so presented that it can readily be used in the classroom.

"Forest Conservation" also has had national distribution in high schools through the co-operation of the Departments of Education. This booklet has an attractive coloured cover design, is illustrated in black and white, is printed on good paper stock, and has the appearance of a high class magazine. The chapters on various phases of forestry were prepared for the purpose of covering the subject with sufficient thoroughness to give a general idea of the subject, and the lesson "quizzes" at the end of each chapter require thought and reasoning. "Forest Conservation" indicates the correlation of the forest with the economic, industrial, agriculture, aesthetic and cultural life of the nation. This book has gone through two editions, and is always in demand 
by the general public as well as the schools. The first edition was in French and English.

Our latest publication, "Native Trees of Canada", with its interesting coloured dust jacket and beautiful coloured plates, is an achievement in fine book-making and will be a splendid addition to libraries throughout Canada. It was off the press in August, and already one of the provinces has arranged for "Native Trees" to be placed in all its school libraries.

The Dominion Forest Service has prepared another publication entitled "The A.B.C.'s of Forest Fire Prevention". It is hoped to have this booklet before the spring fire season. It is designed for use in primary grades, and will be distributed through the co-operation of the Departments of Education of the various provinces. It will be a full colour job, and will help to fill the gap in literature available for primary schools.

The trend in publications of this nature is toward artistic arrangement, beauty of design and profusion of colour. In the words of the old Chinese saying, "A picture is worth 10,000 words", and more and more pictures are being used by the Dominion Forest Service in their publications.

When forestry literature was scarce in $1925 \mathrm{I}$ prepared a set of lectures - fourteen in number-and delivered one a week for fourteen weeks to the students of the Dauphin Normal School. These lectures were given for three years, and the notes for these lectures formed a text when the students went out to teach. The lectures covered important phases of forestry and forest conservation. The students were taken on field excursions, so that the lecture material became part of their actual experience. The content of these lectures was such that they could be given today with but slight changes in statistics. This experience in lecturing to Normal School classes proved to me that there was need for a text for use in schools, and in 1927 I set to work to prepare the little book previously mentioned, "Forestry Lessons".

I believe that conservation material should be especially prepared for the use of Normal School students, and that it should be in such form that they can understand and can adapt it to the needs of the various regions where they are teaching. When teachers know their material, they are in a position to inform.

Sources of forestry material are still limited, and unless teachers have been exposed to conservation material during training days, they will have neither the desire nor the knowledge required to teach it, when there are so many subjects competing for attention.

All material for teaching the fundamentals of forest conservation should be prepared with the utmost care in order to meet the requirements of modern teaching methods. Publications for schools should be attractive in layout. They should be inspirational as well as factual. Plain facts and figures are not of much value to students unless they can be correlated with actual experience. Since forest conservation is an all-important objective, it is apparent that we must get a far greater amount of acceptable material into the schools.

A large section of the public can be reached through radio plays. We have on our files ten radio plays that were broadcast in 1937 on a national 
hook-up. When I prepared these play scripts I purposely made them dateless so they could be used at any time.

These plays could be re-broadcast, and could also be published and placed in the schools to be used for study in Dramatics and English. These particular plays could be presented in any school as I also prepared a simple introductory script for a stage setting in which a group is listening to the radio. In reality, the parts of the radio play are being read by another group off stage. This adapting device to convert radio scripts to stage use has been used successfully in the Dauphin High School, Manitoba.

More plays could be written by those of us who are interested in radio writing, and with the present awakened interest in the Canadian theatre, there is no reason why stage plays could not be written for school presentation.

From discussion on publications with teachers in many parts of Canada, we find that all are anxious to secure more material on conservation.

I do not pretend to know what all the individual provinces are doing in the way of providing publications for schools, but I am sure that each and every one of us could benefit by an exchange of ideas as to what is and could be the most effective material in a certain region. The problem of telling the story of conservation is so vast and so important that in order to meet the local need, the overall Canadian picture of what is being done would be of great assistance to those engaged in this type of educational activity. 